\title{
Highly Fluorescent Pyreno[2,1-b]pyrroles: First Syntheses, Crystal Structure, and Intriguing Photophysical Properties
}

\author{
Srinivasan Selvi, Shih-Chieh Pu, Yi-Ming Cheng, J im-Min Fang,* and Pi-Tai Chou* \\ Department of Chemistry, National Taiwan University, Taipei 106, Taiwan \\ jmfang@ntu.edu.tw; chop@ntu.edu.tw \\ Received May 13, 2004
}

\begin{abstract}
A series of pyrrole anal ogues of benzo[a]pyrene have been synthesized in which pyreno[2,1-b]pyrrole exhibits highly fluorescent properties in solution as well as in crystalline form even possessing strong $\pi-\pi$ stacking. The $\pi$-stacking-induced fluorescence spectral changes lead to future applications such as molecular recognition feasible upon chemical modification.
\end{abstract}

\section{Introduction}

By careful choice of molecular frame and functionality, it is possible to fine-tune the electronic properties of organic compounds. ${ }^{1-4}$ Modulation of the HOMO-LUMO levels in turn changes the redox properties and optical performance of the molecule. ${ }^{5-7}$ The design and synthesis of brightly emissive molecules having a polycyclic aromatic backbone allowing for alterations in emission properties are a subject of current research in view of their potential applications as chemosensors ${ }^{8}$ and in optoelectronic devices. ${ }^{9,10}$ Pyrene, for example, has been employed as a prototypical fluorophore in this approach. ${ }^{11-15}$ In many cases, the pyrene chromophore is connected to a complexation site via a flexible, nonconjugated tether. These systems are shown to display ratiometric fluorescence properties, i.e., the normal versus excimer emission, sensitive to the presence of guest ions or molecules, and thus act as efficient probes.

(1) Sheats, J . R.; Antoniadis, A.; Hueschen, M.; Leonard, W.; Miller, J .; Moon, R.; Roitman, D.; Stocking, A. Science 1996, 273, 884.

(2) Bao, Z.; Lovinger, A. J .; Brown, J. J . Am. Chem. Soc. 1998, 120, 207.

(3) Krebs, F. C.; Spanggard, H. J . Org. Chem. 2002, 67, 7185

(4) Burn, P. L.; Kraft, A.; Baigent, D. R.; Bradley, D. D. C.; Brown, A. R.; Friend, R. H.; Gymer, R. W.; Holmes, A. B.; J ackson, R. W. J . Am. Chem. Soc. 1993, 115, 10117.

(5) Miura, R.; Urano, Y.; Tanaka, K.; Nagano, T.; Ohkubo, K. Fukuzumi, S. J. Am. Chem. Soc. 2003, 125, 8666.

(6) Moylan, C. R.; Miller, R. D.; Twieg, R. J .; Betterton, K. M.; Lee,

V. Y.; Matray, T. J .: N guyen, C. Chem. Mater. 1993, 5, 1499.

(7) Brédas, J .-L. Adv. Mater. 1995, 7, 263.

(8) DeSilva, A. P.; Gunaratne, H. Q. N.; Gunnlaugsson, T.; Huxley, A. J. M.; M cCoy, C. P.; Rademacher J. T.; Rice, T. E. Chem. Rev. 1997, 97, 1515.

(9) Schmidt-Mende, L.; Fechtenkötter, A.; Müllen, K.; Moons, E.; Friend R. H.; MacKenzie, J . D. Science 2001, 293, 1119.

(10) Percec, V.; Glodde, M.; Bera, T. K.; Miura, Y.; Shiyanovskaya I.; Singer, K. D.; Balagurusamy, V. S. K.; Heiney, P. A.; Schnell, I.; Rapp, A.; Spiess, H.-W.; Hudson S. D.; Duan, H. Nature 2002, 419, 384.

(11) Yang, J .-S.; Lin C.-S.; H wang, C.-Y. Org. Lett. 2001, 3, 889

(12) Mahara, A.; I wase, R.; Sakamoto, T.; Yamana, K.; Yamaoka T.; Murakami A. Angew. Chem., Int. Ed. 2002, 41, 3648.

(13) Liao, J .-H.; Chen, C.-T.; Fang, J.-M. Org. Lett. 2002, 4, 561.

(14) Kim, J. S.; Noh, K. H.; Lee, S. H.; Kim, S. K.; Kim S. K.; Yoon, J. J . Org. Chem. 2003, 68, 597.

(15) Kuo, L.-J .; Liao, J .-H.; Chen, C.-T.; Huang, C.-H.; Chen, C.-S.; Fang, J .-M. Org. Lett. 2003, 5, 1821.
For further extension of pyrene systems, heterocyclic pyrene analogues such as pyreno[2,1-b]furan, ${ }^{16}$ pyreno$[2,1-b]$ thiophene, ${ }^{17}$ pyreno[2,1-b]pyridine, ${ }^{18}$ pyreno[2,1-c]pyridine, ${ }^{18}$ and pyreno[1,2-b]pyridine ${ }^{18}$ have been developed. However, to our knowledge, there is no report of pyreno[2,1-b]pyrrole systems. The lower ionization potential as well as versatile functionality of the pyrrole moiety make synthetic and photophysical approaches toward pyreno[2,1-b]pyrroles of great interest in view of both the advancement of the existing synthetic tools and the development of functional materials. Herein, we report a new series of heteroatomic polycyclic fluorophore molecules 1-9 based on the parent moiety of pyreno[2,1b]pyrrole.

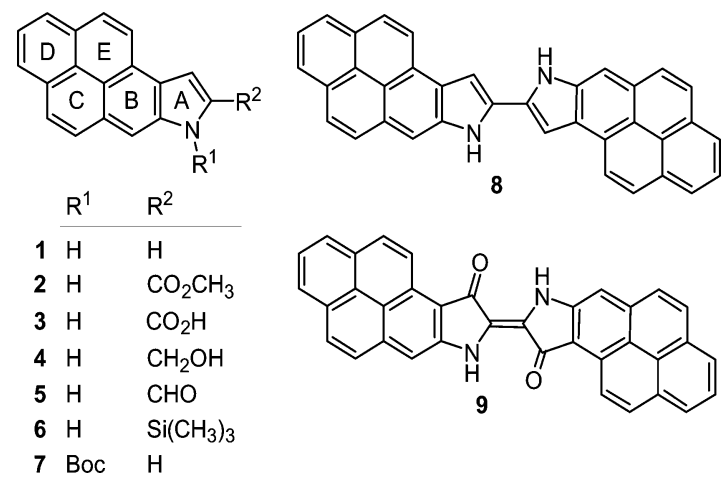

\section{Results and Discussion}

Pyreno[2,1-b]pyrrole (1) was efficiently prepared by using a Hemetsberger $-\mathrm{K}$ nittel reaction ${ }^{19}$ (Scheme 1 ) that incorporated a Knoevenagel condensation of pyrene-1al dehyde $\mathbf{A}$ and methyl azidoacetate in the presence of

(16) Demerseman, P.; Einhorn, J .; Gourvest, J .-F.; Royer, R. J . Heterocycl. Chem. 1985, 22, 39.

(17) Pratap, R.; Tominaga, Y.; Lee, M. L.; Castle, R. N. J . Heterocyd. Chem. 1981, 18, 973.

(18) Whaley, W. M.; Meadow, M.; Robinson, C. M. J . Org. Chem. 1954, 19, 973.

(19) Murakami, Y.; Watanabe, T.; Suzuki, H.; Kotake, N.; Takahashi, T.; Toyonari, K.; Ohno, M.; Takase, K.; Suzuki, T.; Kondo, K. Chem. Pharm. Bull. 1997, 45, 1739. 
SCHEME $1^{\text {a }}$<smiles>O=Cc1ccc2ccc3cccc4ccc1c2c34</smiles>

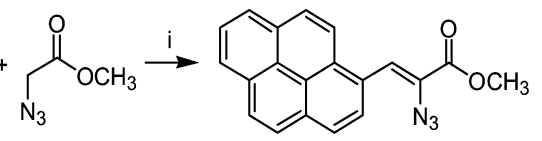

B<smiles></smiles><smiles>O=C(O)c1cc2c(cc3ccc4cccc5ccc2c3c45)[nH]1</smiles><smiles>[R]c1cc2c(cc3ccc4cccc5ccc2c3c45)[nH]1</smiles>

$\begin{array}{ll}\text { vi } \longrightarrow 5 & \mathrm{R}=\mathrm{CH}_{2} \mathrm{OH} \\ 5 & \mathrm{R}=\mathrm{CHO}\end{array}$

a Reagents and reaction conditions: (i) $\mathrm{N}_{3} \mathrm{CH}_{2} \mathrm{CO}_{2} \mathrm{CH}_{3}, \mathrm{NaOCH}_{3}$, THF, -15 to $0{ }^{\circ} \mathrm{C}, 6 \mathrm{~h}, 87 \%$; (ii) $\mathrm{PhCH}_{3}, 110{ }^{\circ} \mathrm{C}, 4 \mathrm{~h}, 92 \%$; (iii) $\mathrm{KOH}, \mathrm{THF}, \mathrm{H}_{2} \mathrm{O}$, reflux, $2 \mathrm{~h}, 97 \%$; (iv) Cu, quinoline, $220^{\circ} \mathrm{C}, 2 \mathrm{~h}$, 91\%; (v) $\mathrm{LiAlH}_{4}, \mathrm{THF}, 25^{\circ} \mathrm{C}, 3 \mathrm{~h}, 96 \%$; (vi) $\mathrm{MnO}_{2}, \mathrm{CH}_{2} \mathrm{Cl}_{2}, 25^{\circ} \mathrm{C}$, $3 \mathrm{~h}, 82 \%$.

sodium methoxide at -15 to $0{ }^{\circ} \mathrm{C}$, forming B. Further pyrolysis of $\mathbf{B}$ in toluene afforded the methyl ester derivative of pyrrole-fused pyrene $\mathbf{2}$. Saponification of $\mathbf{2}$ using aqueous $\mathrm{KOH}$ in THF gave acid 3, which upon decarboxylation by catalysis of copper in redistilled quinoline afforded $\mathbf{1}$. Thus, pyrene-1-aldehyde was converted by a four-step sequence to give pyreno[2,1-b]pyrrole (1) in $71 \%$ overall yield. On the other hand, reduction of ester $\mathbf{2}$ with $\mathrm{LiAlH}_{4}$ afforded alcohol $\mathbf{4}$, which on oxidation with $\mathrm{MnO}_{2}$ yielded aldehyde 5 . The synthesis of pyreno[2,1-b]pyrroles $\mathbf{1}-\mathbf{5}$ was achieved with $>80 \%$ yield at each step.

The fused-pyrrole ring also exhibits versatile chemistry of indole types. ${ }^{20}$ Lithiation reactions of the N-Boc derivative of pyreno[2,1-b]pyrrole (7) occurred smoothly at $-78{ }^{\circ} \mathrm{C}$. Thus, 7 was lithiated with t-BuLi and reacted with electrophiles such as trimethylsilyl chloride, tributyltin chloride, and iodine to afford the corresponding 2-substituted products 7-Si, 7-Sn, and 7-I. The N-Boc group was readily removed by heating $\left(110^{\circ} \mathrm{C}\right)$ in DMF solution, giving 6 from 7-Si. The Stille coupling reaction between 7-Sn and 7-I also proceeded smoothly by catalysis of palladium under standard conditions, ${ }^{21}$ yiel ding bis(pyrenopyrrole) 8 (Scheme 2). Oxidation of 1 with cumyl hydroperoxide in the presence of $\mathrm{Mo}(\mathrm{CO})_{6}$ offered the oxidative coupling product $\mathbf{9}$ of indigoid-type structure.22

The appearance of characteristic pattern of a pyrrole $\mathrm{NH}$ signal, e.g., at $\delta 8.54$ for $\mathbf{1}$, and other signals in the ${ }^{1} \mathrm{H}$ NMR spectra are consistent with their assigned structures. Further structural information for $\mathbf{1}$ and $\mathbf{2}$ was rendered by the single-crystal X-ray diffraction analyses. Compound $\mathbf{l}$ in EtOAc solution and compound $\mathbf{2}$ in benzene solution were slowly evaporated to grow the

(20) (a) Eisenstadt, E. ACS Symp. Ser. 1985, 283, 327. (b) Snieckus, V. Chem. Rev. 1990, 90, 879.

(21) (a) Stille, J . K. Angew. Chem., Int. Ed. Engl. 1986, 25, 508. (b) Farina, V.; Krishnamurthy, V.; Scott, W. J . Org. React. 1997, 50, 1. (22) Yoshihiro, Y.; Usaji, T.; Shinobu, A.; I sao, H. Eur. Patent 0339 887 Al, 1989.

\section{SCHEME 2a}

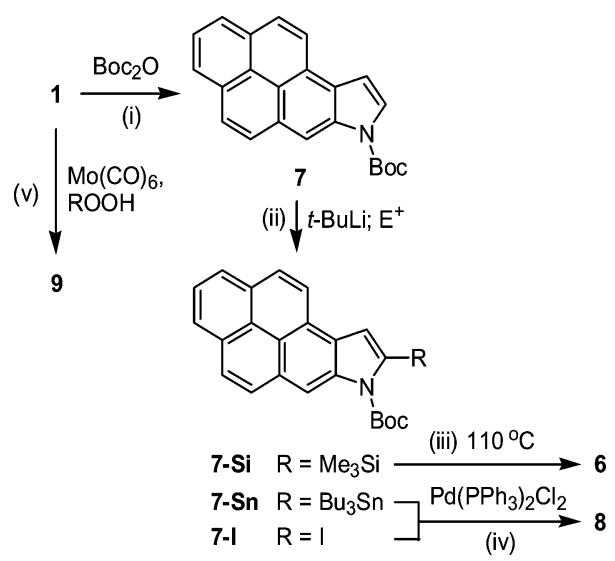

a Reagents and reaction conditions: (i) $\mathrm{Boc}_{2} \mathrm{O}$, cat. DMAP, THF, $25^{\circ} \mathrm{C}, 5 \mathrm{~h}, 99 \%$; (ii) t-BuLi, THF, $\mathrm{Me} \mathrm{S}_{3} \mathrm{SiCl}$ (for 7-Si) or $\mathrm{Bu}_{3} \mathrm{SnCl}$ (for 7-Sn) or $\mathrm{I}_{2}$ (for 7-I), $-78{ }^{\circ} \mathrm{C}, 2 \mathrm{~h}$; (iii) DMF, $110{ }^{\circ} \mathrm{C}, 5 \mathrm{~h}, 78 \%$ from 7; (iv) cat. $\mathrm{Pd}\left(\mathrm{PPh}_{3}\right)_{2} \mathrm{Cl}_{2}, \mathrm{DMF}, 110^{\circ} \mathrm{C}, 5 \mathrm{~h}, 62 \%$; (v) cumyl hydroperoxide, cumene, cat. $\mathrm{Mo}(\mathrm{CO})_{6}, \mathrm{C}_{6} \mathrm{H}_{5} \mathrm{CO}_{2} \mathrm{H}, 80{ }^{\circ} \mathrm{C}, 5 \mathrm{~h}, 70 \%$.

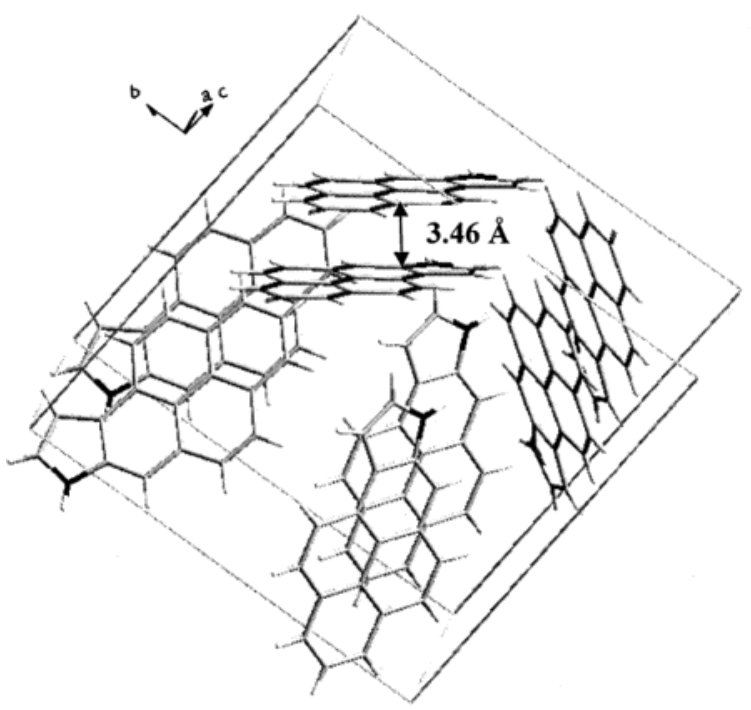

FIGURE 1. Molecular packing diagram of 1 showing $\pi-\pi$ interaction with an interplanar distance of $3.46 \AA$.

single crystals suitable for X-ray analyses. Compound $\mathbf{1}$ crystallized in an orthorhombic configuration. It is clear that pyrenopyrrole energetically favors an offset parallel $\pi$ stacking between two proximal molecular planes separated by a distance of $3.46 \AA$ (Figure 1), e.g., the B-ring of one molecule stacking on top of the E-ring of the other molecule (referring structure 1 for ring assignments). The intercentroid distance is $3.65 \AA$, e.g., from the B-ring center of one molecule to the E-ring center of the other parallel molecule. The packing is analogous to that of pyrene, ${ }^{23}$ which also shows an offset parallel stacking with the hydrogens roughly over ring centers with an interplanar distance of $3.5 \AA$.

Ester $\mathbf{2}$ crystallizes as a triclinic configuration, which shows a salient dimeric feature due to the formation of dual hydrogen bonds between the pyrrole $\mathrm{NH}$ of one molecule and the ester carbonyl group of the other molecule with an $\mathrm{NH}---\mathrm{O}=\mathrm{C}$ distance of $2.06 \AA$.

(23) (a) Winnik, F. Chem. Rev. 1993, 93, 587. (b) Camerman, A.; Trotter, J. Acta Crystallogr. 1965, 18, 636. 
TABLE 1. Photophysical Parameters of Pyreno[2,1-b]pyrroles 1-9

\begin{tabular}{|c|c|c|c|c|c|}
\hline compd & $\lambda_{\max }^{\mathrm{abs}}(\mathrm{nm})$ & $\epsilon_{\max }\left(\mathrm{M}^{-1} \mathrm{~cm}^{-1}\right)$ & $\lambda_{\max }^{\mathrm{em}}(\mathrm{nm})$ & $\Phi_{\mathrm{f}}^{\mathrm{a}}$ & lifetime (ns) \\
\hline 1 & $384^{b}(456)^{c}$ & 37300 & $398^{b}(538)^{c}$ & $0.95^{b}(0.15)^{c, d}$ & $2.80^{b}(2.63)^{c}$ \\
\hline 2 & $400^{e}(458)^{c}$ & 53400 & $404^{e}(590)^{c}$ & 0.82 & $2.29^{e}(2.33)^{c}$ \\
\hline 3 & $398^{b}(493)^{c}$ & 52600 & $403^{b}(574)^{c}$ & 0.82 & $2.31^{b}(1.32)^{c}$ \\
\hline 4 & $388^{\mathrm{b}}$ & 34800 & $404^{b}$ & 0.96 & $2.64^{b}$ \\
\hline 5 & $416^{b}$ & 23600 & $438^{b}$ & 0.61 & $2.55^{\mathrm{b}}$ \\
\hline 6 & $392^{\mathrm{b}}$ & 24100 & $406^{b}$ & 0.95 & $2.41^{\mathrm{b}}$ \\
\hline 7 & $371^{b}$ & 51300 & $401^{b}$ & 0.27 & $8.29^{b}$ \\
\hline 8 & $473^{e}$ & 88475 & $482^{e}$ & 0.50 & $1.40^{\mathrm{b}}$ \\
\hline 9 & $687^{e}$ & 11150 & $707^{e}$ & $0.0076^{f}$ & $0.42^{b}$ \\
\hline
\end{tabular}

a $\Phi_{\mathrm{f}}$ calculated relative to coumarins at $298 \mathrm{~K}$ for compounds $1-8$. ${ }^{\mathrm{b}}$ Data acquired in $1 \times 10^{-5} \mathrm{M}$ EtOAc. ${ }^{\mathrm{c}}$ Data acquired in crystal. ${ }^{d} \Phi_{f}$ measured by an integrating sphere $(300 \mathrm{~K})$ with an accuracy of $\pm 15 \%$. e Data acquired in $1 \times 10^{-5} \mathrm{M} \mathrm{THF}$. ${ }^{\mathrm{f}} \Phi_{\mathrm{f}}$ calculated relative to 4-(dicyanomethylene)-2-methyl-6-(p-dimethylaminostyryl)-4H-pyran at $298 \mathrm{~K}$.

Compounds 1-3 were screened for their mutagenic properties relative to benzo[a]pyrene ${ }^{24}$ to ascertain their toxicity before further studies and were found to be in no way comparable with benzo[a]pyrene.

The detailed photophysical properties of $\mathbf{1}-\mathbf{9}$ are listed in Table 1, while typical absorption and emission spectra in solution and crystal are included in the Supporting Information. The peak wavelength of the lowest $\pi \rightarrow \pi^{*}$ absorption for $\mathbf{1}-\mathbf{9}$ shows a significant bathochromic shift of $>50 \mathrm{~nm}$ with respect to that of pyrene. Table 1 also clearly indicates that C(2) substitution with a carbonyl functional group decreases the energy gap, whereas $N$ (1) functionalization by Boc results in an opposite trend. Molecular modeling for $\mathbf{1}$ based on the ZI NDO/S method 25 (eight occupied and unoccupied molecular levels) gave an allowed singlet HOMO $\rightarrow$ LUMO excitation $(f \sim 0.78$, indicating that the breakdown of symmetry from $D_{2 h}$ (pyrene) to $C_{s}$ (pyreno[2,1-b]pyrrole) drastically facilitates the optical transition. The cal culated energy gap of 27778 $\mathrm{cm}^{-1}$ for $\mathbf{1}$ is qualitatively consistent with the experimental value of $26455 \mathrm{~cm}^{-1}$. Theoretical approaches also reveal that $\pi$ electrons are spread over the entire molecular framework for both HOMO and LUMO levels (see the Supporting Information). Thus, a key contribution for the substituent effect is believed to be the modulation of $\pi$-electron conjugation, consistent with the experimental results, in which aldehyde $\mathbf{5}$ has the lowest energy gap among $\mathbf{1 - 5}$ due to its greatest tendency of extending the $\pi$ electron delocalization. Conversely, an electronwithdrawing Boc group at the $\mathrm{N}(1)$ position (e.g., 7) localizes the N (1) lone pair el ectrons and hence increases the energy gap.

All analogues except for $\mathbf{9}$ exhibit strong fluorescence with quantum efficiency of $\Phi_{f}>0.27$ in EtOAc or THF . In the cases of $\mathbf{1}, \mathbf{4}$, and $\mathbf{6}, \Phi_{\mathrm{f}}$ is even near unity. Unlike the remarkable excimer formation for pyrene in solution, ${ }^{26}$ the emission spectra of 1-9 turned out to be virtually concentration independent in the range of $10^{-6}$ $10^{-4} \mathrm{M}$. In contrast, the emission resulting from the $\pi$ stacking is obvious in the solid, as supported by the $>100$ $\mathrm{nm}$ red shift of the peak wavel ength $\left(\lambda_{\max } \sim 538 \mathrm{~nm}\right)$ in a single crystal relative to that in solution for $\mathbf{1}$. The lack of excimer emission for $\mathbf{1}$ in solution can plausibly be rationalized by the much shorter radiative lifetime of $<5$

(24) Ketcha, D. M. Prog. Heterocycl. Chem. 2002, 14, 114.

(25) Zerner, M. C. In Reviews in Computational Chemistry; Lipkowitz, K. B., Boyd, D. B., E ds.; VCH: New York, 1991; Vol. II, p 313.

(26) Laposa, J. D.; Lim, E. C.; Kellogg, R. E. J . Chem. Phys. 1965, 42,3025 .

6676 J. Org. Chem., Vol. 69, No. 20, 2004 ns, i.e., the more allowed transition, for the pyreno$\left[2,1\right.$-b]pyrrole moiety than that for pyrene $(>200 \mathrm{~ns}){ }^{26}$ Therefore, the rate of bimolecular excimer formation is too slow to compete with the intramolecular decay processes. Support of this viewpoint is given by increasing the concentration of 1 up to $\sim 10^{-3} \mathrm{M}$, the emission of which exhibited a shoulder with a peak wavelength at $\sim 510 \mathrm{~nm}$ and is tentatively ascribed to the excimer emission (see the Supporting Information). Unfortunately, due to the highly emissive monomer fluorescence in EtOAc as well as in other solvents, further resolution of the excimer emission for compound $\mathbf{1}$ is not possible at this stage.

Finally, it is noteworthy that $\mathbf{9}$ is treated as an analogue of indigo with extended $\pi$ conjugation. The absorption and emission peak maxima were measured to be 687 and $710 \mathrm{~nm}$, respectively, in ethyl acetate, which, to our knowledge, possesses the lowest energy gap among current existing indigo derivatives. The small emission energy gap, al ong with a relatively low $\Phi_{f}$, can be qualitatively explained by the energy gap law pertaining to the radiationless decay, concluding that the radiationless deactivation should increase upon decreasing the energy gap of the transition. ${ }^{27}$ Nevertheless, 9 is particularly intriguing in the photovol taic/dye application due to its high extinction coefficients covering the entire visible range.

\section{Conclusion}

We have developed a new series of pyrrole analogues of benzo[a]pyrene. All monomeric pyreno[2,1-b]pyrrole and derivatives are highly emissive in solution. Despite the strong $\pi$ stacking interaction, the fluorescence yield in the crystal, e.g., 1, is anomalously high and can be tentatively rationalized by its intact packing structure so that the defective sites are obscure. The difficulty in forming excimer emission in solution for the pyreno[2,1b]pyrrole moiety renders a superiority in devel oping, e.g., a dual pyreno[2,1-b]pyrrole sensor based on the intramolecular excimer formation upon binding the analytes. In this case, the probe concentrations can be maximized free from the intermolecular excimer perturbation. From this work, we have established structural groundwork to aid in the further design of new materials applicable in various areas such as supramolecular science, optoelectronics, and biological probe.

(27) Siebrand, W. J . Chem. Phys. 1967, 47, 2411. 


\section{Experimental Section}

Methyl 2-Azido-3-(1-pyrenyl)propenoate (B). Sodium methoxide ( $2.16 \mathrm{~g}, 40 \mathrm{mmol}$ ) was taken in a flask fitted with a pressure equalizer. The system was evacuated and kept under argon atmosphere. Methanol ( $30 \mathrm{~mL})$ was introduced, and the flask was cooled to $-15^{\circ} \mathrm{C}$. The pressure equalizer was charged with a THF solution $(40 \mathrm{~mL})$ of pyrene-1-aldehyde $(2.3 \mathrm{~g}, 10 \mathrm{mmol})$ and methyl azidoacetate $(4.6 \mathrm{~g}, 40 \mathrm{mmol})$. The mixture was slowly added over a period of $3 \mathrm{~h}$ with constant stirring at $-15^{\circ} \mathrm{C}$. The mixture was allowed to stir for an additional $3 \mathrm{~h}$ at $0{ }^{\circ} \mathrm{C}$ and then poured into ice-water, stirred for $10 \mathrm{~min}$, filtered, washed with water, and dried. The obtained compound B (2.84 g, 87\%) was sufficiently pure and was used for the next step without further purification: ${ }^{1} \mathrm{H}$ NMR $\left(\mathrm{CDCl}_{3}, 400 \mathrm{MHz}\right) \delta 8.64(\mathrm{~d}, \mathrm{~J}=8.0 \mathrm{~Hz}, 1 \mathrm{H}), 8.28(\mathrm{~d}, \mathrm{~J}$ $=9.2 \mathrm{~Hz}, 1 \mathrm{H}), 8.19(\mathrm{~d}, \mathrm{~J}=7.6 \mathrm{~Hz}, 2 \mathrm{H}), 7.97-8.17(\mathrm{~m}, 5 \mathrm{H})$, $7.95(\mathrm{~s}, 1 \mathrm{H}), 3.99(\mathrm{~s}, 3 \mathrm{H}) ;{ }^{13} \mathrm{C} \mathrm{NMR}\left(\mathrm{CDCl}_{3}, 100 \mathrm{MHz}\right) \delta 163.9$ $131.8,131.1,130.5,129.6,128.3,128.2,127.3,127.3,126.7$, $126.6,126.0,125.8,125.6,124.6,124.5,124.4,122.7,122.6$, 53.2; HR-FAB-MS calcd for $\mathrm{C}_{20} \mathrm{H}_{13} \mathrm{~N}_{3} \mathrm{O}_{2} 327.1008$, found $\mathrm{m} / \mathrm{z}$ $327.1013\left(\mathrm{M}^{+}\right)$.

Pyreno[2,1-b]pyrrole (1). A mixture of acid 3 (855 mg, 3 $\mathrm{mmol})$, copper powder (135 $\mathrm{mg})$, and doubly distilled quinoline $(15 \mathrm{~mL})$ was refluxed $\left(220^{\circ} \mathrm{C}\right)$ for $2 \mathrm{~h}$. The reaction mixture was cooled to room temperature, and the copper was filtered. The filtrate was poured into cold water, brought to $\mathrm{pH} 4$ with $2 \mathrm{~N} \mathrm{HCl}$, and extracted with ethyl acetate $(3 \times 100 \mathrm{~mL})$. The EtOAc layer was washed with $10 \% \mathrm{HCl}(5 \times 50 \mathrm{~mL}), 10 \%$ $\mathrm{NaHCO}_{3}(5 \times 50 \mathrm{~mL})$, and water $(2 \times 100 \mathrm{~mL})$. The organic layer was dried over $\mathrm{Na}_{2} \mathrm{SO}_{4}$ and concentrated under reduced pressure. The residue was purified by column chromatography using EtOAc/hexane (2:8) to yield pure compound $\mathbf{1}$ (658 mg, 91\%): $\mathrm{mp} 172-174{ }^{\circ} \mathrm{C} ;{ }^{1} \mathrm{H} \mathrm{NMR}\left(\mathrm{CDCl}_{3}, 400 \mathrm{MHz}\right) \delta 8.58(\mathrm{~d}$, $\mathrm{J}=9.2 \mathrm{~Hz}, 1 \mathrm{H}), 8.54(\mathrm{~s}, 1 \mathrm{H}), 8.22(\mathrm{~d}, \mathrm{~J}=9.2 \mathrm{~Hz}, 1 \mathrm{H}), 8.19$ $(\mathrm{d}, \mathrm{J}=7.6 \mathrm{~Hz}, 1 \mathrm{H}), 8.11(\mathrm{~d}, \mathrm{~J}=7.6 \mathrm{~Hz}, 1 \mathrm{H}), 8.08(\mathrm{~s}, 1 \mathrm{H})$, $8.01(\mathrm{~d}, \mathrm{~J}=9.2 \mathrm{~Hz}, 1 \mathrm{H}), 7.91-7.96(\mathrm{~m}, 2 \mathrm{H}), 7.53(\mathrm{t}, \mathrm{J}=2.8$ $\mathrm{Hz}, 1 \mathrm{H}), 7.36(\mathrm{~m}, 1 \mathrm{H}) ;{ }^{13} \mathrm{C} \mathrm{NMR}\left(\mathrm{CDCl}_{3}, 100 \mathrm{MHz}\right) \delta 133.4$, $130.5,130.2,127.7,127.1,126.6,125.5,125.4,124.9,124.3$, $124.2,123.8,123.6,123.6,123.2,119.8,107.6,101.1$; HR-FABMS calcd for $\mathrm{C}_{18} \mathrm{H}_{11} \mathrm{~N} 241.0891$, found $\mathrm{m} / \mathrm{z} 241.0898\left(\mathrm{M}^{+}\right)$.

Methyl Pyreno[2,1-b]pyrrole-2-carboxylate (2). Compound $\mathbf{B}(2.62 \mathrm{~g}, 8 \mathrm{mmol})$ in dry toluene $(150 \mathrm{~mL})$ was slowly added to boiling toluene $(200 \mathrm{~mL})$ over $3 \mathrm{~h}$. The reaction mixture was refluxed for an additional $1 \mathrm{~h}$ after nitrogen evolution had ceased. The mixture was cooled and filtered to yield ester 2 as a yellow crystalline compound $(2.20 \mathrm{~g}, 92 \%)$ : $\mathrm{mp} 242-244{ }^{\circ} \mathrm{C} ;{ }^{1} \mathrm{H}$ NMR (DMSO-d $\left.6,400 \mathrm{MHz}\right) \delta 12.59$ (s, 1 $\mathrm{H}), 8.75(\mathrm{~d}, \mathrm{~J}=9.2 \mathrm{~Hz}, 1 \mathrm{H}), 8.30(\mathrm{~d}\rfloor=,8.8 \mathrm{~Hz}, 1 \mathrm{H}), 8.22-$ $8.28(\mathrm{~m}, 2 \mathrm{H}), 8.17(\mathrm{~s}, 1 \mathrm{H}), 8.14(\mathrm{~d}, \mathrm{~J}=7.6 \mathrm{~Hz}, 1 \mathrm{H}), 8.11(\mathrm{~d}$, $\mathrm{J}=9.2 \mathrm{~Hz}, 1 \mathrm{H}), 9.90-8.0(\mathrm{~m}, 2 \mathrm{H}), 3.97(\mathrm{~s}, 3 \mathrm{H}) ;{ }^{13} \mathrm{C} \mathrm{NMR}$ (DMSO-d 6,100 MHz) $\delta 160.8,134.8,129.5,129.4,128.5,127.5$, $127.3,126.8,125.9,124.7,124.4,124.3,124.1,123.1,122.9$, $122.4,118.9,108.6,106.4,51.9$; HR-FAB-MS calcd for $\mathrm{C}_{20} \mathrm{H}_{13}$ $\mathrm{NO}_{2}$ 299.0946, found $\mathrm{m} / \mathrm{z} 299.0948\left(\mathrm{M}^{+}\right)$.

Pyreno[2,1-b]pyrrole-2-carboxylic Acid (3). KOH (449 $\mathrm{mg}, 8 \mathrm{mmol}$ ) was added to a solution of ester $2(1.2 \mathrm{~g}, 4 \mathrm{mmol})$ in THF $(80 \mathrm{~mL})$ and $\mathrm{H}_{2} \mathrm{O}(20 \mathrm{~mL})$. The mixture was refluxed for $2 \mathrm{~h}$. The THF was removed under reduced pressure, and the residue was acidified with $6 \mathrm{~N} \mathrm{HCl}$. The precipitate was filtered, washed with water, and dried to afford acid 3 (1.11 g, 97\%): $\mathrm{mp} 280^{\circ} \mathrm{C} \mathrm{dec} ;{ }^{1} \mathrm{H}$ NMR (DMSO-d $\left.6,400 \mathrm{MHz}\right) \delta 12.44$ $(\mathrm{s}, 1 \mathrm{H}), 8.75(\mathrm{~d}, \mathrm{~J}=8.8 \mathrm{~Hz}, 1 \mathrm{H}), 8.29(\mathrm{~d}, \mathrm{~J}=8.8 \mathrm{~Hz}, 1 \mathrm{H})$, $8.23-8.27(\mathrm{~m}, 2 \mathrm{H}), 8.08-8.16(\mathrm{~m}, 3 \mathrm{H}), 7.95(\mathrm{~d}, \mathrm{~J}=8.8 \mathrm{~Hz}, 1$ $\mathrm{H}), 7.93(\mathrm{~d}, \mathrm{~J}=7.6 \mathrm{~Hz}, 1 \mathrm{H}) ;{ }^{13} \mathrm{C}$ NMR (DMSO-d $\left.6,100 \mathrm{MHz}\right)$ $\delta 161.9,134.7,129.5,129.4,128.8,128.2,127.6,126.7,125.7$, $124.5,124.3,124.1,123.9,122.9,122.6,118.8,108.6,105.9$; HR-FAB-MS calcd for $\mathrm{C}_{19} \mathrm{H}_{11} \mathrm{NO}_{2} 285.0790$, found $\mathrm{m} / \mathrm{z} 285.0792$ $\left(\mathrm{M}^{+}\right)$.

(Pyreno[2,1-b]pyrrol-2-yl)methanol (4). Ester 2 (299 mg, $1 \mathrm{mmol})$ in anhydrous THF (10 mL) was added dropwise, under an argon atmosphere, to a stirred suspension of $\mathrm{LiAlH}_{4}$ (152 mg, 4 mmol) in THF (20 mL). The reaction mixture, after being stirred at room temperature for $3 \mathrm{~h}$, was quenched by dropwise addition of $1 \% \mathrm{HCl}$. The product was extracted with EtOAc, washed with water, dried over $\mathrm{Na}_{2} \mathrm{SO}_{4}$, and evaporated to dryness to give alcohol 4 (262 mg, 96\%): $\mathrm{mp} 158-160{ }^{\circ} \mathrm{C}$; ${ }^{1} \mathrm{H}$ NMR (DMSO- $\left.\mathrm{d}_{6}, 400 \mathrm{MHz}\right) \delta 11.78(\mathrm{~s}, 1 \mathrm{H}), 8.58(\mathrm{~d}, \mathrm{~J}=$ $8.8 \mathrm{~Hz}, 1 \mathrm{H}), 8.25(\mathrm{~s}, 1 \mathrm{H}), 8.16-8.22(\mathrm{~m}, 2 \mathrm{H}), 8.08-8.14(\mathrm{~m}$, $2 \mathrm{H}), 7.80-7.93(\mathrm{~m}, 2 \mathrm{H}), 7.24(\mathrm{~s}, 1 \mathrm{H}), 5.47(\mathrm{t}, \mathrm{J}=5.6 \mathrm{~Hz}, 1$ $\mathrm{H}), 4.86(\mathrm{~d}, \mathrm{~J}=5.6 \mathrm{~Hz}, 2 \mathrm{H}) ;{ }^{13} \mathrm{C}$ NMR (DMSO-d $\left.6,100 \mathrm{MHz}\right)$ $\delta 142.3,134.3,130.4,130.1,128.4,126.2,125.8,125.4,124.6$, $124.4,124.3,124.1,123.8,123.6,122.7,119.0,108.5,97.5,57.2$; HR-FAB-MS calcd for $\mathrm{C}_{19} \mathrm{H}_{13} \mathrm{NO} 271.0997$, found m/z 271.0990 $\left(\mathrm{M}^{+}\right)$.

Pyreno[2,1-b]pyrrole-2-carboxaldehyde (5). Activated $\mathrm{MnO}_{2}$ (165 mg, $1.9 \mathrm{mmol}$ ) was added to a solution of alcohol 5 (271 $\mathrm{mg}, 1 \mathrm{mmol})$ in anhydrous $\mathrm{CH}_{2} \mathrm{Cl}_{2}(100 \mathrm{~mL})$. The mixture was stirred at room temperature for $3 \mathrm{~h}$ and filtered over a short path of Celite, which was subsequently washed with $\mathrm{CH}_{2^{-}}$ $\mathrm{Cl}_{2}(100 \mathrm{~mL})$ followed by THF (100 mL). After removal of the solvents, the residue was purified by column chromatography using EtOAc/hexane (1:3) to yield pure aldehyde 5 (220 mg, 82\%): $\mathrm{mp} 265^{\circ} \mathrm{C} \mathrm{dec} ;{ }^{1} \mathrm{H}$ NMR (DMSO-d $\left.6,400 \mathrm{MHz}\right) \delta 12.63$ $(\mathrm{s}, 1 \mathrm{H}), 10.03(\mathrm{~s}, 1 \mathrm{H}), 8.75(\mathrm{~d}, \mathrm{~J}=9.2 \mathrm{~Hz}, 1 \mathrm{H}), 8.33-8.38(\mathrm{~m}$, $2 \mathrm{H}), 8.29(\mathrm{~d}, \mathrm{~J}=8.0 \mathrm{~Hz}, 1 \mathrm{H}), 8.25(\mathrm{~s}, 1 \mathrm{H}), 8.18(\mathrm{~d}, \mathrm{~J}=7.2$ $\mathrm{Hz}, 1 \mathrm{H}), 8.11(\mathrm{~d}, \mathrm{~J}=9.2 \mathrm{~Hz}, 1 \mathrm{H}), 7.93-8.01(\mathrm{~m}, 2 \mathrm{H}) ;{ }^{13} \mathrm{C}$ NMR (DMSO- $\left.d_{6}, 100 \mathrm{MHz}\right) \delta 182.3,136.8,136.4,130.4,129.9$, $127.9,127.8,127.0,125.5,125.3,125.1,124.9,124.7,123.2$, $122.9,119.4,112.8,109.1$; HR-FAB-MS calcd for $\mathrm{C}_{19} \mathrm{H}_{11} \mathrm{NO}$ 269.0841, found $\mathrm{m} / \mathrm{z} 269.0843\left(\mathrm{M}^{+}\right)$.

2-(Trimethylsilyl)pyreno[2,1-b]pyrrole (6). Under an argon atmosphere, a solution of $\mathbf{7}(341 \mathrm{mg}, 1 \mathrm{mmol}$ ) in THF $(20 \mathrm{~mL})$ was cooled to $-78^{\circ} \mathrm{C}$. To this solution was added tertbutyllithium ( $1.1 \mathrm{mmol}, 0.7 \mathrm{~mL}$ of $1.6 \mathrm{M}$ pentane solution) dropwise. The mixture was stirred for $3 \mathrm{~h}$ at $-78{ }^{\circ} \mathrm{C}$, and the electrophile of trimethylsilyl chloride ( $1.2 \mathrm{mmol}, 0.15 \mathrm{~mL}$ ) in THF (10 mL) was added dropwise. After being stirred for $2 \mathrm{~h}$ at $-78{ }^{\circ} \mathrm{C}$, the reaction mixture was poured into cold water and extracted with EtOAc. The organic phase was dried over $\mathrm{Na}_{2} \mathrm{SO}_{4}$ and evaporated to dryness. The crude N-(tert-butoxycarbonyl)-2-(trimethylsilyl)pyreno[2,1-b]pyrrole (7-Si) was dissolved in DMF $(15 \mathrm{~mL})$ and heated at $110{ }^{\circ} \mathrm{C}$ for $5 \mathrm{~h}$. The solution was cooled, poured into water, and extracted with EtOAc. The organic layer was washed with water, dried over $\mathrm{Na}_{2} \mathrm{SO}_{4}$, and concentrated in vacuo. The crude material was purified by column chromatography using EtOAc/hexane (2: 8) to afford compound 6 (244 mg, 78\%): mp $161-163{ }^{\circ} \mathrm{C} ;{ }^{1} \mathrm{H}$ $\mathrm{NMR}\left(\mathrm{CDCl}_{3}, 400 \mathrm{MHz}\right) \delta 8.64(\mathrm{~s}, 1 \mathrm{H}), 8.59(\mathrm{~d}, \mathrm{~J}=8.8 \mathrm{~Hz}, 1$ $\mathrm{H}), 8.20(\mathrm{~d}, \mathrm{~J}=8.8 \mathrm{~Hz}, 1 \mathrm{H}), 8.16(\mathrm{~d}, \mathrm{~J}=7.6 \mathrm{~Hz}, 1 \mathrm{H}), 8.13(\mathrm{~s}$, $1 \mathrm{H}), 8.08(\mathrm{~d}, \mathrm{~J}=7.6 \mathrm{~Hz}, 1 \mathrm{H}), 8.01(\mathrm{~d}, \mathrm{~J}=8.8 \mathrm{~Hz}, 1 \mathrm{H}), 7.86-$ $7.93(\mathrm{~m}, 2 \mathrm{H}), 7.54(\mathrm{~s}, 1 \mathrm{H}), 0.47(\mathrm{~s}, 9 \mathrm{H}) ;{ }^{13} \mathrm{C} \mathrm{NMR}\left(\mathrm{CDCl}_{3}, 100\right.$ $\mathrm{MHz}) \delta 140.0,136.8,130.9,130.6,128.2,127.8,127.0,125.9$, $125.8,124.8,124.7,124.5,124.1,123.8,123.5,120.2,109.8$, 107.5, $-0.93(3 \times)$; HR-FAB-MS calcd for $\mathrm{C}_{21} \mathrm{H}_{19} \mathrm{NSi} 313.1287$, found $\mathrm{m} / \mathrm{z} 313.1290\left(\mathrm{M}^{+}\right)$.

N-(tert-B utoxycarbonyl)pyreno[2,1-b]pyrrole (7). To a solution of compound $\mathbf{1}$ (241 $\mathrm{mg}, 1 \mathrm{mmol}$ ) in THF (20 mL) were added 4-(dimethylamino)pyridine $(5 \mathrm{mg})$ and di-tert-butyl dicarbonate $(240 \mathrm{mg}, 1.1 \mathrm{mmol})$. The reaction mixture was stirred at room temperature for $5 \mathrm{~h}$ under an argon atmosphere. After evaporation of the solvent, the residual solid mass was purified by a short neutral alumina column using EtOAc/hexane (15:85) to get compound 7 (337.6 mg, 99\%): $\mathrm{mp}$ $152-154{ }^{\circ} \mathrm{C} ;{ }^{1} \mathrm{H}$ NMR $\left(\mathrm{CDCl}_{3}, 400 \mathrm{MHz}\right) \delta 8.98(\mathrm{~s}, 1 \mathrm{H}), 8.39$ $(\mathrm{d}, \mathrm{J}=8.8 \mathrm{~Hz}, 1 \mathrm{H}), 8.02-8.22(\mathrm{~m}, 4 \mathrm{H}), 7.85-8.0(\mathrm{~m}, 3 \mathrm{H})$, $7.30(\mathrm{~d}, \mathrm{~J}=3.6 \mathrm{~Hz}, 1 \mathrm{H}), 1.79(\mathrm{~s}, 9 \mathrm{H}) ;{ }^{13} \mathrm{C} \mathrm{NMR}\left(\mathrm{CDCl}_{3}, 100\right.$ $\mathrm{MHz}) \delta 149.5,132.7,130.6,130.4,128.4,128.1,127.1,126.2$, $126.1,125.5,124.9,124.8,124.5,124.3,123.3,122.8,120.9$, 111.7, 105.3, 83.9, $28.6(3 \times)$; HR-FAB-MS calcd for $\mathrm{C}_{23} \mathrm{H}_{19} \mathrm{NO}_{2}$ 341.1416, found $\mathrm{m} / \mathrm{z} 341.1421\left(\mathrm{M}^{+}\right)$.

2,2 -Bis(pyreno[2,1-b]pyrrole) (8). According to the procedure similar to that for 6, the lithiated 7 (341 mg, $1 \mathrm{mmol}$ ) was treated with iodine ( $305 \mathrm{mg}, 1.2 \mathrm{mmol}$ ) and tributyltin chloride $(0.33 \mathrm{~mL}, 1.2 \mathrm{mmol})$, respectively, to give $\mathrm{N}$-(tert- 
butoxycarbonyl)-2-iodopyreno[2,1-b]pyrrole (7-I, 415 mg, 89\%) and $\mathrm{N}$-(tert-butoxycarbonyl)-2-(tributylstannyl)pyreno[2,1-b]pyrrole (7-Sn, $448 \mathrm{mg}, 71 \%$ ). A mixture of 7-I (234 mg, 0.5 $\mathrm{mmol}$ ), 7-Sn (378 mg, $0.6 \mathrm{mmol}$ ), and $\mathrm{Pd}\left(\mathrm{PPh}_{3}\right)_{2} \mathrm{Cl}_{2}$ (11 mg, $0.015 \mathrm{mmol}, 3 \mathrm{~mol} \%)$ in DMF $(20 \mathrm{~mL})$ was heated at $110^{\circ} \mathrm{C}$. After $5 \mathrm{~h}$, the reaction mixture was cooled and poured into water. The dark green precipitates were collected by filtration, washed with a small amount of EtOAc and $50 \mathrm{~mL}$ of water, and then dried in vacuo to yield compound 8 (149 mg, 62\%): $\mathrm{mp}>340^{\circ} \mathrm{C} ;{ }^{1} \mathrm{H}$ NMR (DMSO- $\left.\mathrm{d}_{6}, 400 \mathrm{MHz}\right) \delta 12.53(\mathrm{~s}, 2 \mathrm{H})$, $8.66(\mathrm{~d}, \mathrm{~J}=8.9 \mathrm{~Hz}, 2 \mathrm{H}), 8.37(\mathrm{~s}, 2 \mathrm{H}), 8.32(\mathrm{~d}, \mathrm{~J}=8.9 \mathrm{~Hz}, 2$ $\mathrm{H}), 8.24(\mathrm{~d}, \mathrm{~J}=7.6 \mathrm{~Hz}, 2 \mathrm{H}), 8.13-8.21(\mathrm{~m}, 4 \mathrm{H}), 8.04(\mathrm{~s}, 2 \mathrm{H})$, 7.91-7.99 (m, $4 \mathrm{H}) ;{ }^{13} \mathrm{C}$ NMR (DMSO-d $\left.6,100 \mathrm{MHz}\right) \delta 135.5$, $133.0,130.5,130.3,128.3,127.1,126.9,125.3,125.3,125.0$, $124.8,124.6,124.1,123.5,123.0,119.6,108.21,98.4$; HR-FABMS calcd for $\mathrm{C}_{36} \mathrm{H}_{20} \mathrm{~N}_{2} 480.1626$, found $\mathrm{m} / \mathrm{z} 480.1623\left(\mathrm{M}^{+}\right)$.

Indigoid Derivative of Pyreno[2,1-b]pyrrole (9). A mixture of pyreno[2,1-b]pyrrole (205 $\mathrm{mg}, 0.85 \mathrm{mmol}$ ), benzoic acid (10 mg, $0.085 \mathrm{mmol}$ ), molybdenum hexacarbonyl (2.3 mg, $0.0085 \mathrm{mmol})$, and cumyl hydroperoxide $(0.46 \mathrm{~mL}, 3 \mathrm{mmol})$ in cumene $(10 \mathrm{~mL})$ was heated at $80{ }^{\circ} \mathrm{C}$ for $5 \mathrm{~h}$. The reaction mixture was cooled, filtered, and washed successfully with cumene and methanol. The black solid was dried in vacuo to get compound 9 (152.5 mg, 70\%), $\mathrm{mp}>300{ }^{\circ} \mathrm{C}$. The NMR spectrum was not recorded due to insufficient solubility of $\mathbf{9}$ in various solvents: FT-IR $(\mathrm{KBr}) \mathrm{cm}^{-1} 3430,3045,1726,1633$, 1587, 1547, 1434, 1129, 1089, 851, 678, 638; HR-FAB-MS calcd for $\mathrm{C}_{36} \mathrm{H}_{18} \mathrm{~N}_{2} \mathrm{O}_{2}$ 510.1368, found $\mathrm{m} / \mathrm{z} 510.1376\left(\mathrm{M}^{+}\right)$.

Spectroscopic and Dynamic Measurements. Steadystate absorption and emission spectra were recorded at 298 $\mathrm{K}$. The excitation light source of the fluorimeter has been corrected by the rodamine B spectrum. In addition, the wavelength-dependent characteristics of the monochromator and photomultiplier have been calibrated by recording the scattered light spectrum of the corrected excitation light from a diffused cell in the $220-700 \mathrm{~nm}$ ranges. To obtain the precise extinction coefficient, five different concentrations ranging from $5 \times 10^{-5}$ to $5 \times 10^{-7} \mathrm{M}$ were performed. Coumarin 102 in ethanol was used as a reference, assuming a yield of 0.93 with a 400-nm excitation, to determine the fluorescence quantum yields of compounds $\mathbf{1 - 7}$ in solution. For compound 8, coumarin 480 was used as a reference $\left(\lambda_{\mathrm{em}}=480 \mathrm{~nm}\right.$, Exciton, Inc.), assuming a quantum yield of 0.93 in ethanol. ${ }^{28}$ 4-(Dicyanomethylene)-2-methyl-6-(p-dimethylaminostyryl)-4Hpyran $\left(\mathrm{CH}_{2} \mathrm{Cl}_{2}, \lambda_{\mathrm{em}}=615 \mathrm{~nm}\right)$ in methanol was used as a reference for compound $\mathbf{9}$, assuming a quantum yield of 0.43 with a $430 \mathrm{~nm}$ excitation. ${ }^{29}$

Fluorescence quantum yields were calculated according to the following equation 30

$$
\Phi_{\text {sample }}=\Phi_{\text {std }}\left[\frac{\mathrm{I}_{\text {sample }}}{\mathrm{I}_{\text {std }}}\right]\left[\frac{\mathrm{A}_{\text {std }}}{\mathrm{A}_{\text {sample }}}\right]\left[\frac{\mathrm{n}_{\text {sample }}}{n_{\text {std }}}\right]^{2}
$$

In this equation, $\Phi_{\text {sample }}$ and $\Phi_{\text {std }}$ are the quantum yields of sample and standard, respectively; $I_{\text {sample }}$ and $I_{\text {std }}$ are the integrated emission intensities of the sample and the standard, respectively; $A_{\text {sample }}$ and $A_{\text {std }}$ are the absorbance of the sample and standard, respectively; and $n_{\text {sample }}$ and $n_{\text {std }}$ are the refractive indexes of the sample and standard solutions, respectively.

A configuration of front-face excitation was used to measure the emission of the solid sample in which the cell was made

(28) J ones, G., II ; J ackson, W. R.; Halpern, A. M. Chem. Phys. Lett. 1980, 72, 391.

(29) Drake, J . M.; Lesiecki, M. L.; Camaioni, D. M. Chem. Phys. Lett. 1985, 113, 530

(30) (a) Demas, J . N.; Crosby, G. A. J . Phys. Chem. 1971, 75, 991. (b) Eaton, D. F. CRC Handbook of Organic Photochemistry I.; Scaiano, J. C., Ed.; CRC Press: Boca Raton, FL, 1989; pp 233-235. by assembling two edge-polished quartz plates with various Teflon spacers. A combination of appropriate filters was used to avoid the interference from the scattering light. An integrating sphere ( $300 \mathrm{~K}$ ) was applied to measure the quantum yield in the solid state, in which the solid sample film was prepared via either the spin-coating or vapor-deposition method and was excited by a 365-nm $\mathrm{Ar}^{+}$laser line. The resulting luminescence was acquired by an intensified chargecoupled detector for subsequent quantum yield analyses.

Nanosecond lifetime studies were performed by a photoncounting system with a hydrogen-filled/or a nitrogen lamp as the excitation source. Data were analyzed using the nonlinear least-squares procedure in combination with an iterative convolution method. The emission decays were analyzed by the sum of exponential functions, which allows partial removal of the instrument time broadening and consequently renders a temporal resolution of $\sim 200$ ps. For dynamic measurements, sample solution was degassed via three freeze-pump-thaw cycles to avoid the oxygen-quenching interference.

Theoretical Calculation Method.Vertical transition energies $\left(S_{0} \rightarrow S_{n}\right)$ of compound $\mathbf{1}$ were obtained by the semiempirical Zerner's spectroscopic parametrization for intermediate neglect of differential overlap (ZINDO/S) method, ${ }^{25}$ coupled with a single configuration interaction $(\mathrm{SCl})$ technique, which involved eight occupied and unoccupied molecular levels, corresponding to the first branches of $\pi$ - and $\pi^{*}$-type molecular orbitals. Hereby, the geometry was optimized with the AM 1 (Austin Model 1) method. ${ }^{31}$ All semiempirical AM1 and ZI NDO/S calculations were conducted with the HYPERCHEM program. ${ }^{32}$ As a result, the $\pi$ electrons are spread over the entire molecular framework for both HOMO and LUMO levels (see the Supporting Information).

X-ray Analysis. The crystals were mounted on a glass fiber. Crystal data were collected on diffractometers installed with monochromatized MoK $\alpha$ radiation, $\lambda=0.71073 \AA$ at $T=295$ K. All structures were solved by using the SHELXS- $97^{33}$ and refined with SHELXL-9734 by full-matrix least-squares mthods on $\mathrm{F}^{2}$ values. Hydrogen atoms were fixed at calculated positions and refined using a riding mode.

Crystal data of $\mathbf{1}$ (from EtOAc): $\mathrm{C}_{18} \mathrm{H}_{11} \mathrm{~N}, \mathrm{M}=241.3$, orthorhombic P $22_{1} 2_{1}, a=4.9960(2) \AA, b=14.4730(7) \AA, c=$ 16.4550(8) $\AA, \alpha=\beta=\gamma=90^{\circ}, V=1189.81(9) \AA^{3}, Z=4, D_{c}=$ $1.347 \mathrm{~g} \mathrm{~cm}^{-3}, 7379$ reflections collected, unique $2710\left(\mathrm{R}_{\mathrm{int}}=\right.$ $0.0860)$, final indices $[\mathrm{I}>2 \sigma(\mathrm{I})] \mathrm{R} 1=0.0748, \mathrm{wR} 2=0.1487$.

Crystal data of $\mathbf{2}$ (from benzene): $\mathrm{C}_{23} \mathrm{H}_{16} \mathrm{NO}_{2}, \mathrm{M}=338.4$, triclinic P-1, $a=7.8320$ (3) $\AA, b=7.9820(5) \AA, c=15.7750(9)$ $\AA, \alpha=97.100(2)^{\circ}, \beta=96.593(2)^{\circ}, \gamma=117.374(2)^{\circ}, V=$ 852.39(8) $\AA^{3}, Z=2, D_{c}=1.318 \mathrm{~g} \mathrm{~cm}^{-3}, 5876$ reflections collected, unique $3786\left(\mathrm{R}_{\text {int }}=0.0593\right)$, final indices $[I>2 \sigma(I)]$ $\mathrm{R} 1=0.0646$, wR2 $=0.1678$.

Acknowledgment. We thank Mr. Yi-Hung Liu (Instrumentation Center, National Taiwan University) for X-ray analyses and the National Science Council for financial support.

Supporting Information Available: Absorption, emission, ${ }^{1} \mathrm{H}$ NMR and ${ }^{13} \mathrm{C}$ NMR spectra, theoretical calculation, ORTEP drawings, crystal data, and bond lengths and angles. This material is available free of charge via the Internet at http://pubs.acs.org.

\section{J O049192X}

(31) Dewar, M. J . S.; Zoebish, E. G.; Healy, E. F.; Stewart, J . J . P. J. Am. Chem. Soc. 1985, 107, 3902.

(32) Hyperchem 6.0, Hypercube, Inc., Gainesville, FL, 1999.

(33) Sheldrick, G. M. Acta Crystallogr. 1990, A46, 467.

(34) Sheldrick, G. M. SHELXL-97, Program for the Refinement of Crystal Structures; University of Göttingen: Göttingen, Germany, 1997. 